\title{
UJI AKTIVITAS SUB FRAKSI DAUN BUNGUR (Lagerstroemia speciosa (L) pers) SEBAGAI ANTIBAKTERI DAN ANTIOKSIDAN
}

\author{
Muhammad Ansar ${ }^{1, *}$, Agung Rahmadani $^{1,2}$, Jaka Fadraersada $^{1}$ \\ ${ }^{1}$ Laboratorium Penelitian dan Pengembangan Kefarmasian "Farmaka Tropis", \\ Fakultas Farmasi, Universitas Mulawarman, Samarinda, Indonesia \\ ${ }^{2}$ Kelompok Bidang Ilmu Farmasi Klinik dan Komunitas, Fakultas Farmasi, \\ Universitas Mulawarman, Samarinda, Indonesia \\ *Email: muhammadansar028@gmail.com
}

\begin{abstract}
ABSTRAK
Daun bungur (Lagerstroemia speciosa (L) pers) merupakan tanaman yang telah digunakan secara empiris sebagai obat. Berdasarkan pendekatan kemotaksonomi diketahui bahwa Ekstrak metanol dari Lythrum salicaria L. dengan famili yang sama dengan Bungur yaitu Lythraceae, mengandung senyawa golongan flavonoid seperti isoviteksin dan isoorientin, yang memiliki aktivitas sebagai antioksidan dan antibakteri, sehingga dapat diduga dalam daun Bungur juga mengandung senyawa golongan metabolit sekunder yang sama. Penelitian ini bertujuan untuk mengetahui aktivitas antibakteri dan antioksidan dari daun bungur. Simplisia daun bungur terlebih dahulu diekstraksi dengan cara maserasi. Kemudian difraksinasi dengan metode padat-cair dengan kromatografi cair vakum dan kolom konvensional. Metode antibakteri yang digunakan dalam penelitian ini adalah metode KLT Bioautografi dan untuk metode antioksidan menggunakan metode DPPH. Hasil penelitian menunjukkan bahwa sub fraksi $\mathrm{G}$ dan $\mathrm{J}$ mempunyai aktivitas sebagai antibakteri dan Sub fraksi H, I dan J mempunyai aktivitas antioksidan.
\end{abstract}

Kata Kunci: DPPH, Kemotaksonomi, KLT Bioautografi

DOI: https://doi.org/10.25026/mpc.v6i1.281

\section{PENDAHULUAN}

Indonesia merupakan negara dengan keanekaragaman hayati terbesar kedua setelah Brazil. Diperkirakan sekitar 30.000 jenis tumbuhan ditemukan di dalam hutan Indonesia dan sekitar 1.260 jenis diantaranya berkhasiat sebagai obat. Tumbuhan yang berpotensi sebagai obat yang telah dibudidayakan saat ini masih sangat sedikit. Oleh karena itu, hutan Indonesia masih merupakan sumber plasma nutfah tumbuhan berkhasiat obat yang potensinya perlu digali secara sungguh-sungguh. ${ }^{2}$ Salah satu tumbuhan yang mengandung senyawa obat yaitu Bungur (Lagerstroemia speciosa Pers.).

Senyawa metabolit sekunder dalam tumbuhan biasanya tersebar merata ke seluruh bagian tumbuhan tetapi dalam kadar yang berbeda-beda. Ekstrak metanol dari Lythrum salicaria L. dengan famili yang sama dengan Bungur yaitu Lythraceae, mengandung senyawa golongan flavonoid seperti isoviteksin dan isoorientin, yang memiliki aktivitas sebagai antioksidan dan antiradang. ${ }^{8}$ 
Flavonoid dapat sebagai antioksidan dengan mekanisme mencegah pembentukan radikal bebas baru dengan memutus reaksi berantai dan mengubahnya menjadi produk yang lebih stabil. $^{7} \quad$ Mekanisme kerja flavonoid sebagai antibakteri adalah membentuk senyawa kompleks dengan protein ekstraseluler dan terlarut sehingga dapat merusak membran sel bakteri dan diikuti dengan keluarnya senyawa intraseluler, sedangkan mekanisme lainnya yaitu menghambat metabolisme energi. ${ }^{6}$ Berdasarkan pendekatan kemotaksonomi tersebut, dapat diduga dalam daun Bungur kemungkinan juga mengandung senyawa golongan metabolit sekunder yang sama. Berdasarkan uji pendahuluan serta belum adanya penelitian mengenai kandungan senyawa yang terkandung dalam daun tumbuhan Bungur, maka perlu dilakukan penelitian tentang isolasi dan identifikasi golongan senyawa metabolit sekunder yang terkandung dalam daun Bungur serta uji aktivitas antibakteri dan antioksidan karena belum adanya uji pendahuluan tentang aktivitas daun Bungur sebagai antibakteri dan antioksidan.

\section{METODOLOGI PENELITIAN}

Alat

Alat penyemprot, autoclave, batang pengaduk, cawan petri, tabung reaksi, LAF, Mikropipet, ose bulat, alat gelas yang lazim digunakan.

\section{Bahan}

Aquades, daun Bungur, DPPH, etil asetat, medium NA, metanol, plat KLT, dan silika gel.

\section{Preparasi dan Pembuatan Ekstrak}

Daun Bungur yang telah diperoleh dibuat menjadi simplisia. Kemudian simplisia Daun Bungur diekstraksi dengan cara maserasi menggunakan pelarut metanol. Sebanyak 337 g simplisia diekstraksi menggunakan pelarut metanol. Kemudian dipekatkan menggunakan rotary evaporator dan dikeringkan pada suhu ruang.

\section{Perhitungan Rendemen}

Rendemen diperoleh dari membandingkan antara bobot fraksi dengan bobot simplisia dikali $100 \%$.

\section{Pengujian Aktivitas Antibakteri Secara Kualitatif (KLT Bioautografi)}

Sebanyak $10 \mathrm{~mL}$ medium yang telah dicampur dengan suspensi bakteri sebanyak $100 \mu \mathrm{L}$ dimasukkan kedalam cawan petri dan dibiarkan memadat. Disiapkan plat KLT $( \pm 7 \mathrm{~cm})$ lalu sub fraksi ditotolkan dengan jarak totolan awal $0.5 \mathrm{~cm}$ dan akhir $0.5 \mathrm{~cm}$, sehingga jaraknya adalah $6 \mathrm{~cm}$. Semua sub fraksi dilarutkan dengan etil asetat secukupnya ( $\pm 2 \mathrm{~mL}$ ), kemudian ditotolkan pada plat KLT dengan eluen n-heksana : etil asetat (8:2) untuk sub fraksi A, B, C, D, E, F, G dan $\mathrm{H}$, eluen $\mathrm{n}$-heksana : etil asetat (7:3) untuk sub fraksi I dan J eluen n-heksana : etil asetat (6:4) untuk subfraksi K. Setelah kering, plat KLT diletakkan di atas permukaan medium dalam cawan petri yang telah bercampur dengan suspensi bakteri selama 60 menit. Inkubasi pada suhu $37^{\circ} \mathrm{C}$ selama $1 \times 24$ jam. Jarak rf spot yang memberikan aktivitas dihitung.

\section{Pengujian Aktivitas Antioksidan Secara Kualitatif (KLT Bioautografi)}

Disiapkan plat KLT $( \pm 7 \mathrm{~cm})$ lalu sub fraksi ditotolkan dengan jarak totolan awal $0.5 \mathrm{~cm}$ dan akhir $0.5 \mathrm{~cm}$, sehingga jaraknya adalah $6 \mathrm{~cm}$. Semua sub fraksi dilarutkan dengan etil asetat secukupnya ( $\pm 2 \mathrm{~mL}$ ), kemudian ditotolkan pada plat KLT dengan eluen n-heksana : etil asetat (8:2) untuk sub fraksi A, B, C, D, E, F, G dan $\mathrm{H}$, eluen $\mathrm{n}$-heksana : etil asetat $(7: 3)$ untuk sub fraksi I dan J, eluen n-heksana : etil asetat (6:4) untuk sub fraksi K. Setelah kering, plat KLT disemprot dengan DPPH kemudian diamati perubahan warna dari ungu menjadi kuning. Jarak rf spot yang memberikan aktivitas dihitung. 


\section{HASIL DAN PEMBAHASAN}

Bungur (Lagerstroemia speciosa (L.) Pers) dapat ditemukan di hutan jati, baik di tanah gersang maupun di tanah subur hutan heterogen berbatang tinggi. Kadang-kadang, bungur ditanam sebagai pohon hias atau pohon pelindung di tepi jalan. Tanaman daun Bungur yang digunakan dalam penelitian ini didapatkan dari daerah Kutai Kartanegara, Kalimantan Timur.

Setelah menjadi simplisia, daun Bungur diekstraksi dengan cara maserasi menggunakan pelarut metanol. Kemudian dilakukan penentuan rendemen, penentuan profil senyawa dan pengujian antibakteri dan antioksidan sub fraksi daun Bungur dengan metode KLT bioautografi dan metode DPPH.

Rendemen merupakan persentase bagian bahan baku yang dapat digunakan dari total bahan baku. Hasil dari penentuan rendemen adalah persentase nilai rendemen dimana semakin tinggi persentase nilai rendemen maka semakin besar peluang bahan baku tersebut untuk dimanfaatkan. Hasil perhitungan nilai rendemen ekstrak metanol daun Bungur dan fraksi daun Bungur dapat dilihat pada Tabel 1 dan Tabel 2.

Metode KLT bioautografi dilakukan untuk mengetahui aktivitas antibakteri. Hasil KLT bioautografi dapat dilihat pada Tabel 3 dan Gambar 1 dan Gambar 2. Hasil KLT bioatugrafi ditunjukkan dengan terbentuknya zona bening pada spot sesuai dengan nilai $\mathrm{Rf}$ nya. Hasil tersebut menunjukkan bahwa metabolit sekunder yang terdapat pada fraksi memiliki aktivitas terhadap bakteri E.coli dan S.aureus.

Nilai Rf ditentukan. pada kromatogram sub fraksi yang memiliki aktivitas antibakteri yang menunjukkan bahwa terdapat 2 spot yaitu subfraksi $G$ dan $J$ dengan nilai $R f$ spot $G=0.25$ dan spot $\mathrm{J}=0.33$.

Metode DPPH dilakukan untuk mengetahui aktivitas antioksidan. Hasil uji antioksidan dapat dilihat pada Tabel 4 dan Gambar 3. Hasil tersebut ditunjukkan dengan perubahan warna dari ungu menjadi kuning pada spot sesuai dengan nilai Rf nya. Hasil tersebut menunjukkan bahwa metabolit sekunder yang terdapat pada fraksi memiliki aktivitas antioksidan.

Nilai Rf ditentukan pada kromatogram sub fraksi yang memiliki aktivitas antioksidan yang menunjukkan bahwa terdapat 3 spot yaitu subfraksi H, I dan J dengan nilai Rf spot $\mathrm{H}=0.25$, spot $\mathrm{I}=0,2$ dan spot $\mathrm{J}=0.33$.

Tabel 1. Rendemen Ekstrak Metanol Daun Bungur.

\begin{tabular}{crccc}
\hline No. & Ekstrak & $\begin{array}{c}\text { Berat Awal } \\
(\text { gram })\end{array}$ & $\begin{array}{c}\text { Berat Akhir } \\
(\text { gram })\end{array}$ & $\begin{array}{c}\text { Rendemen } \\
\%\end{array}$ \\
\hline 1. & Ekstrak metanol & $337 \mathrm{~g}$ & $80 \mathrm{~g}$ & $23 \%$ \\
\hline
\end{tabular}

Tabel 2. Rendemen Fraksi n-Hekana dan Etil Asetat

\begin{tabular}{ccccc}
\hline No. & Fraksi & $\begin{array}{c}\text { Berat Awal } \\
(\text { gram })\end{array}$ & $\begin{array}{c}\text { Berat Akhir } \\
(\mathrm{gram})\end{array}$ & $\begin{array}{c}\text { Rendemen } \\
\%\end{array}$ \\
\hline 1. & n-Heksana & $337 \mathrm{~g}$ & $1 \mathrm{~g}$ & $0,29 \%$ \\
2. & Etil Asetat & $337 \mathrm{~g}$ & $6 \mathrm{~g}$ & $1,78 \%$ \\
\hline
\end{tabular}


Tabel 3. Pengujian Aktivitas Antibakteri Pada Fraksi A-K

\begin{tabular}{ccccc}
\hline No. & Fraksi & Mikroba Uji & Hasil & Keterangan \\
\hline 1. & A & E.coli \& S.aureus & - & Tidak memiliki aktivitas antibakteri \\
2. & B & E.coli \& S.aureus & - & Tidak memiliki aktivitas antibakteri \\
3. & C & E.coli \& S.aureus & - & Tidak memiliki aktivitas antibakteri \\
4. & D & E.coli \& S.aureus & - & Tidak memiliki aktivitas antibakteri \\
5. & E & E.coli \& S.aureus & - & Tidak memiliki aktivitas antibakteri \\
6. & F & E.coli \& S.aureus & - & Tidak memiliki aktivitas antibakteri \\
7. & G & E.coli\& S.aureus & + & Memiliki aktivitas antibakteri \\
8. & H & E.coli \& S.aureus & - & Tidak memiliki aktivitas antibakteri \\
9. & I & E.coli \& S.aureus & - & Tidak memiliki aktivitas antibakteri \\
10. & J & E.coli\& S.aureus & + & Memiliki aktivitas antibakteri \\
11. & K & E.coli \& S.aureus & - & Tidak memiliki aktivitas antibakteri \\
\hline
\end{tabular}
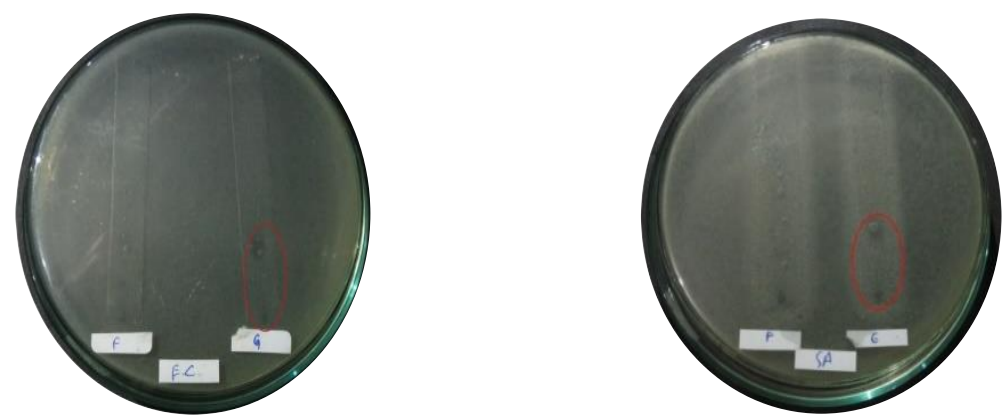

Gambar 1. Hasil Pengujian Aktivitas Antibakteri Pada Fraksi G
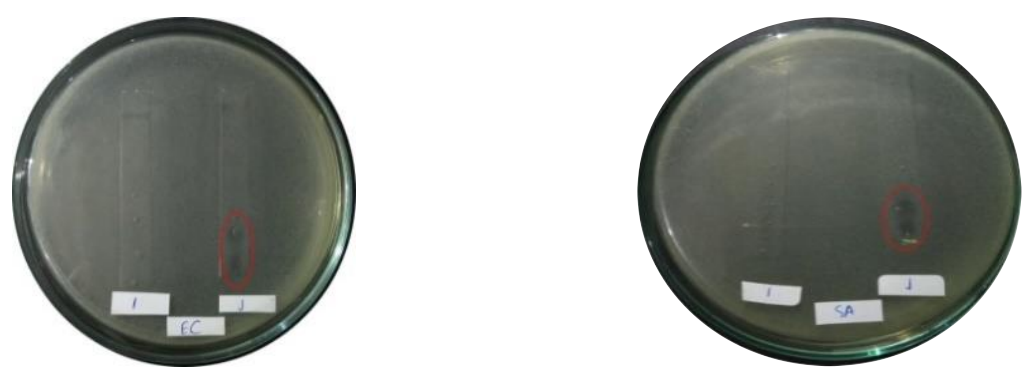

Gambar 2. Hasil Pengujian Aktivitas Antibakteri Pada Fraksi J

Tabel 4. Pengujian Aktivitas Antioksidan Pada Fraksi A-K

\begin{tabular}{cccc}
\hline No. & Fraksi & Hasil & \multicolumn{1}{c}{ Keterangan } \\
\hline 1. & A & - & Tidak memiliki aktivitas antioksidan \\
2. & B & - & Tidak memiliki aktivitas antioksidan \\
3. & C & - & Tidak memiliki aktivitas antioksidan \\
4. & D & - & Tidak memiliki aktivitas antioksidan \\
5. & E & - & Tidak memiliki aktivitas antioksidan \\
6. & F & - & Tidak memiliki aktivitas antioksidan \\
7. & G & - & Tidak memiliki aktivitas antioksidan \\
8. & H & + & Memiliki aktivitas antioksidan \\
9. & I & + & Memiliki aktivitas antioksidan \\
10. & J & + & Memiliki aktivitas antioksidan \\
11. & K & - & Tidak memiliki aktivitas antioksidan \\
\hline
\end{tabular}



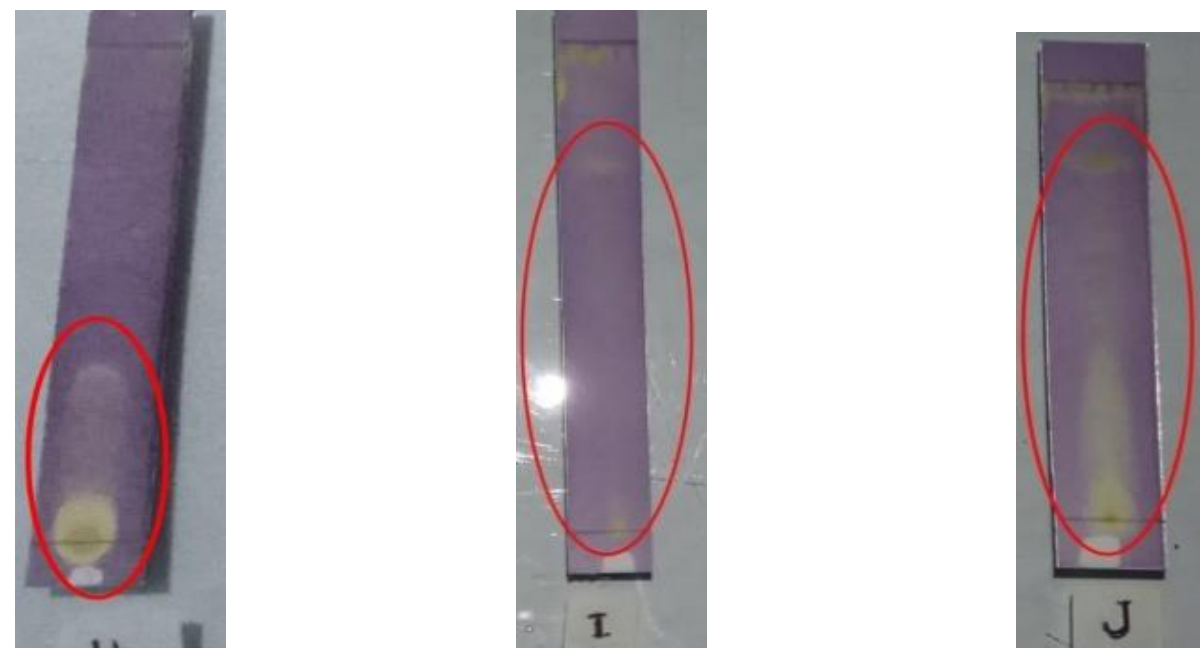

Gambar 3. Hasil Pengujian Aktivitas Antioksidan Pada Fraksi H, I, dan J

Berdasarkan

pendekatan

kemotaksonomi dengan tanaman lythrum salicaria yang familinya sama dengan daun Bungur yaitu lythraceaea mengandung senyawa golongan flavonoid sebagai antioksidan sehingga diduga bahwa daun Bungur yang memiliki aktivitas sebagai antibakteri dan antioksidan merupakan senyawa golongan flavonoid juga. Mekanisme kerja flavonoid sebagai antibakteri adalah membentuk senyawa kompleks dengan protein ekstraseluler dan terlarut sehingga dapat merusak membran sel bakteri dan diikuti dengan keluarnya senyawa intraseluler, sedangkan mekanisme lainnya yaitu menghambat metabolisme energi. Senyawa ini akan mengganggu metabolisme energi dengan cara yang mirip dengan menghambat sistem respirasi, karena dibutuhkan energi yang cukup untuk penyerapan aktif berbagai metabolit dan untuk biosintesis makromolekul). ${ }^{6} \quad$ Flavonoid juga merupakan kelompok senyawa polifenol dengan beberapa sifatnya yang terkenal yaitu melawan radikal bebas, penghambatan hidrolitik dan enzim oksidatif dan tindakan anti-inflamasi. Beberapa bukti menunjukkan bahwa tindakan biologis dari senyawa ini terkait dengan aktivitasnya sebagai antioksidan. ${ }^{7}$

\section{KESIMPULAN}

Sub fraksi $\mathrm{G}$ dan $\mathrm{J}$ daun Bungur (Lagerstroemia speciosa (L) pers.) memiliki aktivitas sebagai antibakteri sedangkan sub fraksi $\mathrm{H}$, I dan $\mathrm{J}$ daun Bungur (Lagerstroemia speciosa (L) pers.) memiliki aktivitas sebagai antioksidan.

\section{DAFTAR PUSTAKA}

[1].Hendrayana, Sumar. 2010. Kimia Pemisahan. Bandung: PT Remaja Rosdakarya.

[2].Isnindar, Subagus Wahyuono, Erna Prawita Setyowati. 2011. Isolasi dan Identifikasi Senyawa Antioksidan Daun Kesemek (Diospyros kaki Thunb.)

[3].Jelendra, H dan Sufyan. 2010. Uji In Vitro Penghambatan Aktivitas Escherichia coli dengan Tepung Cacing Tanah (Lambricus rubellus). Media Peternakan. 30 (1). 41-47.

[4].Jusmiati, A., Rolan Rusli, Laode Rijai. 2015. Aktivitas Antioksidan Kulit Buah Kakao Masak dan Kulit Buah Kakao Muda. Jurnal Sains dan Kesehatan. 1 (1). 34-39

[5].Jawetz, Melnick, Adelberg' s. 2008. Mikrobiologi Kedokteran. Jakarta: Penerbit Buku Kedokteran EGC. 
[6].Ngajow, Mercy., Jemmy Abidjulu, and Vanda S. Kamu. 2013. Pengaruh Antibakteri Ekstrak Kulit Batang Matoa (Pometia pinnata) terhadap Bakteri Staphylococcus aureus secara In vitro. Jurnal Mipa Unsrat Online. 2 (2).

[7].Pourmorad F., S. J. Hosseinimehr, and N. Shahabimajd. 2006. Antioxidant activity, phenol and flavonoid contents of some selected Iranian medicinal plants African. Journal of Biotechnology. 5 (11). 1142-1145.
[8].Tunalier, Z., Kosar, M., Kupeli, E., Calis, I., and Can Baser, K. H., 2007. Antioxidant, Anti-Infalmmatory, Anti-Nociceptive Activities and Composition of Lythrum salicaria L. Extracts. Journal Ethnopharmacology. 110 (3). 